\title{
STRATEGI SCAFFOLDING BERDASARKAN GAYA BELAJAR DAN ARGUMENTASI SISWA: STUDI KASUS PADA PEMBELAJARAN POLA BILANGAN
}

\section{Scaffolding Strategies Based On Student Learning Styles And Arguments: Case Study On Number Pattern Learning}

\author{
Christina M. Laamena*
}

Prodi Pendidikan Matematika, Fakultas Keguruan dan Ilmu Pendidikan, Universitas Pattimura Jln. Ir. M. Putuhena, Kampus Unpatti, Poka-Ambon, 97233, Maluku, Indonesia

e-mail: christinmath18@gmail.com

Corresponding author*

\begin{abstract}
Abstrak
Penelitian ini bertujuan mendeskripsikan strategi scaffolding yang dilakukan guru dalam pembelajaran pola bilangan bagi siswa sekolah dasar. Scaffolding dilakukan berdasarkan dua variabel yaitu (1) gaya belajar visual, auditory dan kinestetik (VAK) serta (2) argumentasi yang telah dikonstruksi siswa. Gaya belajar diselidiki melalui tes dan observasi VAK dan proses pemecahan masalah sedangkan argumentasi siswa dianalisis menggunakan komponen argumentasi Toulmin. Hasil penelitian menunjukkan bahwa strategi scaffolding berbeda dibutuhkan oleh siswa sesuai gaya belajar dan jenis argumen yang dikonstruksi. Pemelajar auditory membutuhkan strategi reviewing dan explaining; pemelajar visual membutuhkan strategi environmental provisions; pemelajar kinestetik membutuhkan strategi restructuring dan reviewing. Khusus pada pemelajar visual dan kinestetik, mereka membutuhkan multimedia sebagai scaffolding yang bermakna. Selama scaffolding argumentasi siswa berkembang dan menghasilkan peningkatan kemampuan problem solving.
\end{abstract}

Kata Kunci: Strategi scaffolding, gaya belajar, argumentasi

\begin{abstract}
This study aims to describe the scaffolding strategy conducted by teachers in learning number patterns for elementary school students. Scaffolding is based on two variables, namely (1) Visual learning style, auditory and kinesthetic (VAK) and (2) arguments that have been constructed by students. Learning styles were investigated through VAK tests and observations and problem-solving processes while student arguments were analyzed using Toulmin argumentation components. The results of the study indicate that different scaffolding strategies are needed by students according to their learning styles and the types of arguments constructed. Auditory learner requires a reviewing and explaining strategy; visual learner requires an environmental provisions strategy; kinesthetic learner requires restructuring and reviewing strategy. Especially for visual and kinesthetic learners, they need meaningful multimedia as scaffolding. During scaffolding, students develop arguments and produce an increase in problem-solving abilities.
\end{abstract}

Keywords: Scaffolding strategy, learning style, argumentation 


\section{PENDAHULUAN}

Setiap orang memiliki gaya belajar tersendiri yang menentukan bagaimana mereka belajar dan berinteraksi dengan lingkungan [4]. Itulah sebabnya gaya belajar merupakan faktor penting [25] yang mempengaruhi keberhasilan seseorang dalam belajar dan menyelesaikan masalah termasuk masalah matematika. Dalam kaitannya dengan proses pembelajaran, pentingnya gaya belajar adalah (1) siswa belajar dengan cara berbeda maka guru juga harus mengajar dengan cara berbeda [7] yaitu menyediakan lingkungan belajar sesuai kebutuhan siswa [19]; (2) tujuan pembelajaran haruslah membekali siswa dengan keterampilan yang berkaitan dengan setiap gaya belajar, tanpa memilih pribadi mana yang lebih baik karena setiap orang harus mengembangkan keterampilan secara efektif sebagai pekerjaannya [19]; (3) guru dapat mengatur banyak hal dalam pendidikan dan komunikasi jika benar-benar mengenali setiap gaya belajar siswa [1].

Gaya belajar adalah cara yang lebih disukai seseorang dalam menerima dan mengelola informasi yang diterima. Menurut Dunn dan Griggs dalam [7], gaya belajar merujuk pada bagaimana seseorang menerima, memfokus, memaknai dan memproses informasi baru kemudian mengubahnya untuk membangun keterampilan baru. Gaya belajar bukanlah kemampuan karena itu merujuk pada bagaimana seseorang memproses informasi dan memecahkan masalah; hal ini berkatian dengan metode terbaik yang dibutuhkan siswa [7].

Gaya belajar berkaitan dengan cara terbaik indera menerima informasi (sensorik) dan menyelesaikannya. Terdapat beberapa cara bagaimana seseorang menggunakan sensorik untuk menerima rangsangan dari lingkungan [15] antara lain, sensorik visual (V), auditori (A) dan kinestetik (K) [18] yang dikenal dengan gaya belajar VAK. Teori gaya belajar VAK menjadi topik yang berkembang dalam penelitian pendidikan akhir-akhir ini termasuk matematika. Prinsip dan teori VAK diperluas pada semua jenis belajar [9] dan pengembangannya serta meningkatkan hasil belajar. Pemelajar visual adalah orang lebih cepat menerima informasi melalui sensorik visual [3]. Mereka lebih cepat memahami apa yang disampaikan jika disajikan dalam bentuk gambar, grafik, peta atau slide. Pemelajar auditori belajar dengan baik melalui mendengarkan. Mereka mendapat manfaat besar dari rangsangan yang diucapkan dan merupakan pendengar yang sangat baik. Mereka menikmati mendengarkan ceramah, berbicara, dan musik. Mereka juga mengingat informasi dengan baik saat diucapkan/didengar selama diskusi [18]. Pemelajar kinestetik belajar paling baik melalui gerakan. Tubuh manusia secara alami dibangun untuk bergerak dan pemelajar kinestetik lebih suka menjaga tubuh mereka bergerak. Pemelajar kinestetik memproses informasi terbaik saat menggerakkan tubuh mereka. Mereka suka menggerakkan tangan dan merespons suara dan musik melalui gerakan fisik seperti bermain atau menyulap benda. Mereka tidak peduli dengan presentasi visual atau aural dan tidak memproses informasi secara efektif ketika disajikan informasi dalam bentuk seperti itu. Sebaliknya, pelajar kinestetik belajar paling baik di lingkungan dimana mereka dapat terlibat secara fisik dalam proses pembelajaran. Tabel 1 menjelaskan indikator-indikator masing-masing gaya belajar.

Gaya belajar sangat penting dalam pembelajaran matematika, khusus bagi siswa Sekolah Dasar (SD). Kemampuan siswa SD dalam menyelesaikan masalah matematika masih sangat dipengaruhi oleh gaya belajar, termasuk kemampuan dalam menyelesaikan masalah pola bilangan. Dari sisi konstruksi pengetahuan, argumentasi yang dikonstruksi siswa selama pemecahan masalah matematika juga menentukan kebenaran klaim atau kesimpulan yang dihasilkan[22]. Masalah matematika dalam matematika sekolah termasuk masalah verbal, gambar dan simbol matematika atau kombinasi semuanya [18]. Ketika masalah matematika yang diberikan berkaitan dengan generalisasi pola bilangan, maka siswa akan menerima dan mengelola informasi berdasarkan gaya belajarnya kemudian menggunakan pengetahuan awal yang telah dimiliki (warrant dan backing), memberikan alasan (warrant) dan memperkuatnya dengan backing dan akhirnya membuat kesimpulan atau klaim. Terkadang, siswa membuat 'tebakan' (menebak pola bilangan) dan menghasilkan beberapa konjektur (klaim awal) lalu mengujinya sebelum menghasilkan klaim akhir. Namun, argumen yang dikonstruksi tidak selamanya valid sehingga menghasilkan kesimpulan yang salah.

Argumentasi Toulmin [21] terdiri dari data, klaim, warrant, backing, rebuttal dan modal qualifier. Klaim adalah pernyataan yang dibuat berdasarkan data. Warrant adalah dasar pikir atau alasan yang digunakan untuk menghasilkan kesimpulan, berupa rumus, definisi, membuat analogi, gambar atau diagram dan grafik. Warrant diperkuat oleh backing sebagai bukti lanjut yang dibutuhkan. Modal qualifier adalah 'frase' yang diberikan pada kesimpulan untuk menunjukkan tingkat kepercayaan atau kekuatan kesimpulan. Rebuttal merupakan kondisi pengecualian untuk klaim karena tidak memenuhi syarat tertentu. 
Guru sebagai pengambil keputusan dalam pembelajaran harus dapat mengidentifikasi gaya belajar dan kelemahan argumentasi siswa serta memberikan scaffolding yang sesuai untuk meningkatkan kemampuan problem solving siswa. Scaffolding memegang peranan penting dalam interaksi pembelajaran matematika agar siswa lebih mandiri dan dapat meningkatkan hasil belajar [9] karena menurut Bakker, dkk [2] ketika guru memberikan scaffolding terjadi dialog antara siswa dengan guru. Dengan demikian, akan terjadi peningkatan pengetahuan [3] khususnya pengetahuan konseptual [4] serta terdapat kesempatan bagi siswa untuk berkembang ke level literasi yang lebih tinggi [14]. Argumentasi dapat mengubah pemahaman siswa dari pemahaman konsep dan prosedur matematika yang "tersembunyi" (tacit) menjadi siswa yang mampu mengemukakan pikirannya dengan jelas dan memberikan alasan tentang idenya [10] dan ini dapat terjadi jika guru memberikan scaffolding yang tepat bukan menjelaskan materi. Berland \& Reiser [13] menjelaskan pentingnya argumentasi dalam memberikan kesempatan kepada guru untuk mengidentifikasi kekuatan dan kelemahan siswa serta meningkatkan pemahaman siswa atau bahkan menantang mereka. Lebih lanjut, menurut Berland \& Reiser [13] dan Landry, dkk [19] ketika guru menantang jawaban siswa, maka terjadi argumentasi yang mendukung terjadinya proses kognitif siswa.

Holton dan Clarke [6] menjelaskan bahwa ada guru yang hanya mampu menyediakan scaffolding dengan cara tertentu tetapi guru tersebut kurang mampu menyediakannya dengan cara yang lain. Guru dengan pengetahuan yang baik akan mampu membimbing siswanya ke arah pemahaman yang mendalam. Hal ini tentu sangat berpengaruh jika guru harus berhadapan dengan siswa yang memiliki gaya belajar berbeda dan membutuhkan scaffolding yang berbeda juga.

Scaffolding digambarkan sebagai dukungan adaptif guru atau orang yang lebih berpengalaman dan bersifat sementara untuk membantu siswa memecahkan masalah yang tidak dapat mereka selesaikan sendiri [12] dan [11]. Gibbons [17] menambahkan bahwa scaffolding hanya bersifat sementara dan dilakukan secara sengaja dan responsif untuk menolong siswa mencapai konsep, keterampilan serta level baru. Oleh karena itu, Wood, Bruner, dan Ross [24] menekankan bahwa scaffolding memungkinkan siswa menyelesaikan masalah, mengerjakan tugas atau mencapai tujuan melampaui usahanya tanpa bantuan. Ini berarti bahwa scaffolding merupakan bantuan yang disediakan oleh orang dewasa kepada siswa yang lebih muda yang memungkinkan siswa tersebut mampu melakukan tugasnya di luar kesanggupannya dan selanjutnya bantuan tersebut dikurangi secara perlahan sampai siswa tersebut mandiri. Berdasarkan pendapat Gibbons, scaffolding yang diberikan seminimal mungkin dan bersifat sementara serta terbatas. Jika pada pertanyaan/arahan pertama siswa sudah dapat menyelesaikan masalahnya, maka scaffolding dihentikan.

Anghileri [12] menjelaskan scaffolding dalam 3 level: Level 1 (environmental provisions) yaitu mengorganisasi siswa, menyediakan benda-benda manipulatif untuk membantu siswa memecahkan masalah; Level 2 (explaining, reviewing dan restructuring), level 2 yaitu bantuan guru yang bersifat menjelaskan, mereview dan merestrukturisasi sebagai respon terhadap kesulitan siswa; dan level 3 (developing conceptual thinking) yaitu guru membantu siswa mengembangkan berpikir konseptual. Di sinilah pemberian scaffolding menjadi keharusan.

van de Pol dkk [12] menjelaskan 3 karakterstik scaffolding ketika terjadi argumentasi antara siswa dan guru, yaitu (1) contingency: strategi yang dipilih tergantung pada kelemahan siswa; (2) fading: menghentikan scaffolding untuk memberikan kesempatan kepada siswa untuk berpikir atau jika siswa telah mencapai tujuan yang diharapkan and (3) transfer of responsibility: merujuk pada aktivitas kognitif atau metakognitif atau sikap siswa. van de Pol dkk [12] mengemukakan enam scaffolding means untuk mendukung aktivitas belajar, (1) Feeding back: mengomentari pekerjaan siswa; (2) giving of hints: memberikan petunjuk atau saran; (3) Instructing: guru menekankan kepada siswa tentang apa yang mereka harus lakukan atau menjelaskan bagaimana sesuatu harus dilakukan dan mengapa; (4) Explaining: merujuk pada penyampaian informasi yang lebih detail atau klarifikasi oleh guru; (5) Modelling: mendemonstrasikan keterampilan-keterampilan khusus; (6) Questioning: memberikan pertanyaan yang membutuhkan jawaban kognitif dan bahasa aktif (argumentasi).

Penelitian ini adalah penelitian lanjutan dari penelitian sebelumnya tentang intervensi individual. Berdasarkan hasil wawancara dengan beberapa siswa ditemukan bahwa siswa mengalami kesulitan dalam menemukan pola bilangan yang disebabkan oleh berbagai hal, seperti tidak memahami bahasa soal, tidak mengingat konsep serta tidak mengetahui cara menyelesaikan masalah. Sumber masalah yang ditemukan adalah siswa memiliki cara berbeda dalam menginterpretasi soal yang dipengaruhi oleh gaya belajar dan juga argumen yang dikonstruksi tidak valid. Penelitian awal merekomendasikan bahwa siswa perlu diberikan scaffolding baik secara klasikal maupun kelompok. Oleh karena itu, penelitian ini bertujuan mendeskripsikan strategi scaffolding yang digunakan guru berdasarkan gaya belajar dan argumentasi siswa kemudian 
menemukan strategi scaffolding yang tepat untuk setiap gaya belajar. Scaffolding yang digunakan mengacu pada enam scaffolding means yang dikemukakan oleh van de Pol., dkk. [12].

\section{METODE PENELITIAN}

Penelitian ini menggunakan mixed method antara metode kuantitatif dan metode kualitatif. Metode kuantitatif bertujuan mengelompokan siswa berdasarkan gaya belajar, sedangkan metode kualitatif bertujuan menyelidiki argumen siswa dan untuk mendeskripsikan jenis scaffolding yang dilakukan guru Sekolah Dasar berdasarkan gaya belajar siswa untuk menumbuhkan argumentasi siswa sehingga dapat meningkatkan kemampuan problem solving siswa. Subjek penelitian adalah siswa kelas lima SD Advent Malang, Jawa Timur yang berjumlah 35 orang dan dipilih menggunakan purposive sampling.

Instrumen yang digunakan terdiri dari 2 yaitu (1) instrumen VAK test yang diadopsi dari [26] yang terdiri dari 54 pernyataan dan masing-masing gaya belajar memuat 18 pernyataan. Instrumen VAK digunakan untuk menentukan gaya belajar siswa; dan (2) Instrumen yang digunakan untuk menganalisis argumentasi sekaligus kemampuan problem solving siswa adalah masalah non rutin yang tidak pernah diberikan oleh guru sebelumnya. Instrumen tentang kemampuan menyelesaikan masalah pola bilangan yang terdiri dari 3 jenis soal. Soal pertama dalam bentuk narasi, soal kedua dalam bentuk gambar dan soal ketiga dalam bentuk bilangan. Perbedaan model soal memungkinkan perbedaan cara penyelesaian masalah siswa berdasarkan gaya belajar.

Berdasarkan hasil gaya belajar siswa dan analisis hasil pekerjaan siswa dalam menyelesaikan masalah pola bilangan, guru mempersiapkan lingkungan belajar seperti benda-benda manipulatif dan media komputer serta mengelompokan siswa tanpa memperhatikan gaya belajar. Pembelajaran dilakukan dalam 2 pertemuan dan pada pertemuan kedua diberikan lagi tes untuk melihat perkembangan pemahaman siswa tentang pola bilangan.

\section{HASIL DAN PEMBAHASAN}

Hasil analisis terhadap tes VAK yang diberikan kepada siswa menunjukkan bahwa terdapat siswa yang hanya memiliki satu gaya belajar (unimodal), siswa dengan dua gaya belajar (bimodal) dan siswa yang memiliki ketiga gaya belajar (multimodal). Persentase siswa berdasarkan gaya belajar disajikan dalam seperti Tabel 1, berikut:

Tabel 1. Persentase Gaya Belajar Siswa

\begin{tabular}{|c|l|c|c|}
\hline No & \multicolumn{1}{|c|}{ Gaya Belajar } & $\begin{array}{c}\text { Banyaknya } \\
\text { Siswa }\end{array}$ & Persentase (\%) \\
\hline 1. & Visual & 11 & 31,4 \\
\hline 2. & Auditory & 5 & 14,3 \\
\hline 3. & Kinestetik & 8 & 22,8 \\
\hline 4. & Bimodal: Visual \& Auditory & 1 & 2,9 \\
\hline 5. & Bimodal: Visual \& Kinestetik & 6 & 17,1 \\
\hline 6. & Bimodal: Auditory \& Kinestetik & 3 & 8,6 \\
\hline 7. & Multimodal: Visual, Auditory \& Kinestetik & 1 & 2,9 \\
\hline \multicolumn{2}{r}{ Jumlah } & 35 & 100 \\
\hline
\end{tabular}

Tabel 1, menunjukkan bahwa gaya belajar yang menonjol adalah visual dan kinestetik. Siswa dengan dua dua gaya belajar dengan jumlah yang paling banyak adalah gaya belajar visual dan kinestetik sedangkan yang paling sedikit adalah siswa dengan gaya belajar visual dan auditory. Siswa dengan multimodal hanya berjumlah satu orang.

Selanjutnya, berdasarkan hasil kerja siswa dalam menyelesaikan masalah pola bilangan diperoleh beberapa penyebab kesalahan siswa, yaitu: (1) kesalahan perceptual visual, (2) kesalahan bahasa dan (3) 
kesalahan aritmetika. Kesalahan perseptual disimpulkan berdasarkan masalah nomor 2; kesalahan bahasa disimpulkan berdasarkan masalah nomor 1 dan 2, sedangkan kesalahan artimetika dapat disimpulkan dari masalah 1, 2 maupun 3. Tabel 2, menjelaskan banyaknya siswa yang melakukan setiap jenis kesalahan.

Tabel 2. Persentase Jenis Kesalahan Siswa

\begin{tabular}{|c|l|c|c|}
\hline No & \multicolumn{1}{|c|}{ Penyebab Kesalahan } & $\begin{array}{c}\text { Banyaknya } \\
\text { Siswa }\end{array}$ & Persentase (\%) \\
\hline 1. & Perseptual Visual & 21 & 60 \\
\hline 2. & Bahasa & 15 & 43 \\
\hline 3. & Aritmetika & 19 & 54 \\
\hline 4. & Perseptual Visual dan Bahasa & 20 & 57 \\
\hline 5. & Perseptual Visual dan Aritmetika & 24 & 69 \\
\hline 6. & Bahasa dan Artimetika & 18 & 51 \\
\hline 7. & Perseptual Visual, Bahasa dan Artimetika & 11 & 31 \\
\hline
\end{tabular}

Terlihat dalam Tabel 2, bahwa kesalahan yang dibuat siswa dominan disebabkan karena kesalahan perseptual dan artimetika juga kesalahan perseptual visual dan bahasa sedangkan penyebab bahasa saja hanya $43 \%$. Selanjutnya hasil pekerjaan siswa dikelompokan berdasarkan jenis warrant dan backing yang digunakan dalam argumentasi untuk menghasilkan klaim, seperti pada Tabel 3

Tabel 3. Argumentasi Berdasarkan Gaya Belajar

\begin{tabular}{|l|l|l|l|}
\hline \multicolumn{1}{|c|}{ Gaya Belajar } & \multicolumn{1}{c|}{ Jenis Warrant } & \multicolumn{1}{c|}{ Jenis backing } & Penyebab Kesalahan \\
\hline Visual & Induktif & backing visual & $\begin{array}{l}\text { Perseptual Visual dan } \\
\text { Aritmetika }\end{array}$ \\
\hline Auditory & Induktif & backing visual & $\begin{array}{l}\text { Perseptual Visual, Bahasa } \\
\text { dan Artimetika }\end{array}$ \\
\hline Kinestetik & Induktif & $\begin{array}{l}\text { backing visual dan } \text { backing } \\
\text { verbal }\end{array}$ & $\begin{array}{l}\text { Perseptual Visual, Bahasa } \\
\text { dan Artimetika }\end{array}$ \\
\hline $\begin{array}{l}\text { Visual dan } \\
\text { Auditory }\end{array}$ & Induktif dan deduktif & $\begin{array}{l}\text { backing visual dan } \text { backing } \\
\text { aritmetika }\end{array}$ & Perseptual Visual \\
\hline $\begin{array}{l}\text { Visual dan } \\
\text { kinestetik }\end{array}$ & Induktif & $\begin{array}{l}\text { backing visual dan backing } \\
\text { rumus }\end{array}$ & Bahasa dan Artimetika \\
\hline $\begin{array}{l}\text { kinestetik dan } \\
\text { Auditory }\end{array}$ & Induktif & $\begin{array}{l}\text { backing visual dan backing } \\
\text { verbal }\end{array}$ & $\begin{array}{l}\text { Perseptual Visual dan } \\
\text { Aritmetika }\end{array}$ \\
\hline $\begin{array}{l}\text { Visual, Auditory \& } \\
\text { Kinestetik }\end{array}$ & Induktif & $\begin{array}{l}\text { backing visual dan backing } \\
\text { verbal }\end{array}$ & Perseptual Visual \\
\hline
\end{tabular}

Berdasarkan data pada Tabel 1, Tabel 2 dan Tabel 3 maka guru menyimpulkan bahwa (1) siswa membutuhkan benda-benda manipulatif untuk mengatasi kesalahan perseptual (2) siswa membutuhkan penjelasan lanjut tentang pertanyaan soal sehingga guru menyediakan umpan balik atau pertanyaanpertanyaan untuk menyadarkan siswa, (3) siswa membutuhkan media komputer yang memuat gambar dan video untuk menarik perhatian mereka. Guru melakukan scaffolding dengan beberapa tahapan dengan pertimbangan bahwa scaffolfding adalah bantuan terbatas sehingga akan dihentikan jika siswa sudah dapat menyelesaikan masalah. Pada setiap tahapan, peneliti mengamati perkembangan argumentasi dan kemajuan jawaban siswa.

Pada scaffolding tahap pertama, guru memprioritaskan pada siswa dengan gaya belajar auditory dan scaffolding bersifat klasikal. Scaffolding tahap kedua difokuskan pada gaya belajar visual dan dilakukan secara berkelompok sedangkan scaffolding tahap keempat difokuskan pada siswa dengan gaya belajar kinestetik dan bersifat kelompok juga individual. Untuk siswa dengan gaya belajar bimodal akan lebih 
mudah memahami karena memiliki dua kemampuan untuk menerima pelajaran. Tabel 4, menjelaskan setiap tahapan dengan deskripsi scaffolding yang digunakan.

Tabel 4. Scaffolding Untuk Ketiga Gaya Belajar

\begin{tabular}{|c|c|c|c|c|}
\hline $\begin{array}{c}\text { Gaya } \\
\text { Belajar }\end{array}$ & $\begin{array}{c}\text { Level } \\
\text { Scaffolding }\end{array}$ & $\begin{array}{l}\text { Strategi } \\
\text { Scaffolding }\end{array}$ & Deskripsi Scaffolding & Tujuan \\
\hline \multirow[t]{3}{*}{ Auditory } & \multirow[t]{3}{*}{ Level 2} & \multirow[t]{2}{*}{ Reviewing } & $\begin{array}{l}\text { Guru meminta siswa memperhatikan kembali } \\
\text { masalah yang diberikan dengan teliti }\end{array}$ & $\begin{array}{l}\text { Meneliti informasi } \\
\text { soal (data) }\end{array}$ \\
\hline & & & $\begin{array}{l}\text { Guru menggali kembali pengetahuan siswa } \\
\text { tentang konsep-konsep yang ditanyakan dalam } \\
\text { soal melalui beberapa pertanyaan }\end{array}$ & $\begin{array}{l}\text { Memunculkan } \\
\text { warrant dan } \\
\text { backing }\end{array}$ \\
\hline & & Explaining & Guru menjelaskan makna soal & \multirow[b]{2}{*}{$\begin{array}{l}\text { Meneliti informasi } \\
\text { soal (data) }\end{array}$} \\
\hline Visual & Level 1 & $\begin{array}{l}\text { environmental } \\
\text { provisions }\end{array}$ & $\begin{array}{l}\text { Guru menggunakan teknologi dengan } \\
\text { memutarkan video tentang kubus satuan yang } \\
\text { menyusun kubus besar }\end{array}$ & \\
\hline \multirow[t]{2}{*}{ Kinestetik } & Level 3 & restructuring & $\begin{array}{l}\text { Guru menyederhanakan masalah untuk } \\
\text { mempermudah siswa memahami masalah }\end{array}$ & $\begin{array}{l}\text { Menyederhanakan } \\
\text { data }\end{array}$ \\
\hline & Level 2 & Reviewing & $\begin{array}{l}\text { Guru memberikan benda-benda manipulatif } \\
\text { untuk menjelaskan masalah agar siswa dapat } \\
\text { memegang dan menghitung sendiri }\end{array}$ & $\begin{array}{l}\text { Memunculkan } \\
\text { warrant dan } \\
\text { backing }\end{array}$ \\
\hline \multirow{2}{*}{$\begin{array}{l}\text { Semua } \\
\text { gaya } \\
\text { belajar }\end{array}$} & \multirow[t]{2}{*}{ Level 3} & \multirow{2}{*}{$\begin{array}{l}\text { developing } \\
\text { conceptual } \\
\text { thinking }\end{array}$} & $\begin{array}{l}\text { Guru menuntun siswa membuat koneksi antara } \\
\text { setiap informasi soal }\end{array}$ & \multirow{2}{*}{$\begin{array}{l}\text { Menemukan } \\
\text { konjektur dan } \\
\text { klaim }\end{array}$} \\
\hline & & & $\begin{array}{l}\text { Memberikan pertanyaan untuk membuat } \\
\text { generalisasi }\end{array}$ & \\
\hline
\end{tabular}

Hasil pengamatan pada setiap tahap scaffolding memberikan hasil yang mencengangkan. Terdapat siswa yang berhasil ketika guru memberikan scaffolding tahap pertama (Level 2) yaitu reviewing dan explaining. Hal ini berlanjut untuk tahapan scaffolding yang berikutnya. Tahapan scaffolding yang dilakukan memberikan hasil yang signifikan terhadap kemampuan problem solving siswa, seperti pada Tabel 5.

Tabel 5. Perubahan Kemampuan Siswa Dalam Menyelesaikan Masalah

\begin{tabular}{|l|c|c|l|}
\hline Tahap Scaffolding & Hasil yang dicapai (\%) & $\begin{array}{c}\text { Jumlah Siswa yang } \\
\text { Berhasil }\end{array}$ & Argumen yang dikonstruksi \\
\hline Pertama & $6(17 \%)$ & $6(17 \%)$ & Warrant induktif dan deduktif \\
\hline Kedua & $13(37 \%)$ & $19(54 \%)$ & Warrant induktif \\
\hline Ketiga & $11(31 \%)$ & $30(85 \%)$ & Warrant induktif \\
\hline Keempat & $25(71 \%)$ & Warrant deduktif \\
\hline
\end{tabular}

Pada Tabel 5, di tahap scaffolding ketiga 30 siswa (85\%) sudah mampu menyelesaikan masalah yang diberikan, namun masih menggunakan cara induktif dengan menghitung satu demi satu. Sehingga dilanjutkan pada tahap keempat untuk memunculkan berpikir konseptual siswa dengan melakukan generalisasi. Dari dari 30 siswa yang berhasil, terdapat 25 siswa yang mampu membuat generalisasi.

Tabel 5, menunjukkan bahwa dari 35 siswa yang mengikuti pembelajaran dan semuanya menghasilkan kesimpulan yang salah maka keberhasilan scaffolding ditunjukkan. Setelah scaffolding tahap pertama, guru memberikan kesempatan kepada siswa untuk memperbaiki pekerjaannya dan 6 siswa (17\%) 
mampu menyelesaikan dengan benar yang menunjukkan bahwa mereka memiliki gaya belajar auditory yang dominan. Setelah scaffolding tahap kedua 13 orang juga berhasil sehingga jumlah siswa yang berhasil 19 (54\%) yang berarti 13 siswa ini memiliki gaya belajar visual yang dominan dan setelah tahap ketiga $85 \%$ siswa berhasil menyelesaikan masalah.

Kemajuan siswa dalam menyelesaikan masalah pola bilangan menunjukkan bahwa scaffolding berhasil meningkatkan kemampuan siswa. Hal ini sejalan dengan pendapat Lin, dkk [24] yang mengatakan bahwa scaffolding merupakan bagian dari strategi pembelajaran yang memenuhi tuntutan peran guru untuk memfasilitasi belajar siswa. Bukan itu saja, scaffolding berhasil mempengaruhi perkembangan kognitif [23] yang ditunjukkan dengan keberhasilan siswa dalam membuat generalisasi. scaffolding juga berhasil membuat pembelajaran efektif.

Perkembangan kognitif siswa dari penalaran induktif menjadi deduktif membuktikan bahwa scaffolding menolong siswa berkembang melewati ZPD (Zone of Proximal Development) mereka karena menurut Vygotsky ZPD dan saffolding berkaitan erat. Menurut Vygotsky [20], setiap anak mempunyai apa yang disebut dengan Zone of Proximal Development (ZPD), yang dikatakan sebagai jarak antara tingkat perkembangan aktual dengan tingkat perkembangan potensial yang lebih tinggi. Dalam hal ini Vygotsky berpendapat bahwa, siswa akan mampu mencapai daerah maksimal bila dibantu secukupnya. Apabila siswa belajar tanpa dibantu, dia akan tetap berada di daerah aktual tanpa bisa berkembang ke tingkat perkembangan potensial yang lebih tinggi.

Video dan benda manipulatif adalah artefak yang digunakan guru sebagai scaffolding dan menyebabkan self correcting sehingga menghasilkan solusi baru yang benar. Siswa Sekolah Dasar masih berada pada tahap berpikir konkrit sehingga peran teknologi dan video merupakan teachers scaffold learning yang baik dan tepat.

\section{KESIMPULAN}

1. Gaya belajar siswa Sekolah Dasar didominasi gaya belajar visual dan kinestetik sehingga diperlukan scaffolding untuk membuat matematika yang abstrak dapat dipahami dengan baik. Siswa dengan gaya belajar visual dan kinestetik yang dominan akan langsung menyadari kesalahannya ketika guru memberikan scaffolding berupa artefak. Siswa dengan gaya belajar auditory akan kembali memperhatikan masalah, mengingat kembali apa yang telah dipelajari setelah penjelasan guru.

2. Tidak semua strategi scaffolding dapat digunakan untuk siswa Sekolah Dasar. Strategi scaffolding yang sesuai dengan gaya belajar auditory adalah reviewing dan explanation; strategi scaffolding yang sesuai untuk gaya belajar visual adalah environmental provisions; strategi scaffolding yang tepat untuk gaya belajar kinestetik adalah restrukturisasi dan reviewing. Sedangkan untuk melakukan generalisasi strategi scaffolding yang tepat adalah developing conceptual thinking.

3. Argumentasi siswa sekolah dasar umumnya didasarkan pada warrant induktif sehingga strategi scaffolding dapat menolong siswa melakukan generalisasi dan mengonstruksi warrant deduktif. Scaffolding dapat memperbaiki argumentasi siswa, backing yang memperlemah warrant dapat berubah menjadi backing yang memperkuat warrant dan menghasilkan klaim valid.

4. Scaffolding tidak dapat dilakukan sekaligus namun bertahap dan harus diberikan secara terbatas sesuai dengan gaya belajar siswa. Scaffolding yang dilakukan sekaligus dapat mengurangi kreativitas siswa dan membuat siswa dengan gaya belajar tertentu tidak berkembang. Teknologi (gambar atau video) dapat digunakan guru sebagai 'artefak' dalam memberikan scaffolding untuk membuat matematika yang abstrak menjadi konkrit sehingga mudah dipahami oleh siswa. Hal ini memudahkan siswa untuk menyelesaikan masalah matematika dan meningkatkan argumentasi siswa.

\section{DAFTAR PUSTAKA}

[1] Abbas Pourhossein Gilakjani dan S. M. Ahmadi, "The Effect of Visual, Auditory, and Kinaesthetic Learning Styles on Language Teaching," International Conferences on Social Science and Huminity, 2011, Vol. 5, pp. 469472.

[2] A. Bakker, J. Smit, and R. Wegerif, "Scaffolding and Dialogic Teaching in Mathematics Education: Introduction and Review," ZDM Math. Educ., Vol. 47, pp. 1047-1065, 2015. 
[3] A. Zohar and F. Nemet, "Fostering Stundets' Knowledge and Argumentation Skill Through Dilemmas in Human Genetics,” J. Res. Sci., Vol. 39, No. 1, pp. 35-62, 2002.

[4] C. S. Asterhan and B. Schwarz, "The Effects of Monological and Dialogical Argumentation on Concept Learning in Evolutionary Theory," J. Educ. Psychol., Vol. 99, No. 3, pp. 626-639, 2007.

[5] C. Tulbure, "Learning Styles, Teaching Strategies and Academic Achievement in Higher Education: A CrossSectional Investigation," Procedia-Soc. Behav. Sci., Vol. 33, pp. 398-402, 2012.

[6] D. Holton and D. Clarke, "Scaffolding and Metacognition," Int. J. Math. Educ. Sci. Technol., Vol. 37, No. 2, pp. 127-143, 2006.

[7] G. Fayombo, "Learning Styles, Teaching Strategies and Academic Achievement Among Some Psychology Undergraduates in Barbados," Caribb. Educ. Res. J. Univ. West Indies, Vol. 3, No. 2, pp. 46-61, 2015.

[8] H. Upu, Djadir, and S. Asyari, "The Fifth Graders' Mathematisation Process in Solving Contextual Problems," World Trans. Eng. Technol. Educ., Vol. 15, No. 2, pp. 195-199, 2017.

[9] J. Anghileri, "Scaffolding Practices That Enhance Mathematics," J. Math. Teach. Educ., Vol. 9, pp. 33-52, 2006.

[10] J. Fielding-Wells, "Inquiry-Based Argumentation in Primary Mathematics: Reflecting on Evidence," Mathematics Education: Yesterday, Today and Tomorrow (Proceedings of the 36th annual conference of the mathematics education research group of Autralasia, 2013, pp. 290-297.

[11] J. Smit and D. van Eerde, "What Counts as Evidence for the Long-Term Realisation of Whole-Class Scaffolding?," Learn. Cult. Soc. Interact., Vol. 2, No. 1, pp. 22-31, 2013.

[12] J. van de Pol, M. Volman, and J. Beishuizen, "Scaffolding in Teacher-Student Interaction: A Decade of Research," Educ. Psychol. Rev., Vol. 22, No. 3, pp. 271-296, 2010.

[13] L. Berland and B. Reiser, "Making Sense of Argumentation and Explanation Science Education," Sci. Educ., Vol. 93, No. 1, pp. 26-55, 2009.

[14] M. Jimenez-Aleixandre and S. Erduran, "Argumentation in Science Education," in Argumentation in Science Education: An Overview, 2007, pp. 3-27.

15] N. Moussa, "The Importance of Learning Styles in Education," Inst. Learn. Styles Journal• Vol., Vol. 1, pp. 1927, 2014.

[16] O. Broza and Y. B. D. Kolikant, "Contingent Teaching to Low-Achieving Students in Mathematics: Challenges and Potential for Scaffolding Meaningful Learning," ZDM - Math. Educ., Vol. 47, No. 7, pp. 1093-1105, 2015.

[17] P. Gibbons, "Scaffolding Language, Scaffolding Learning: Teaching Second Language Learners in the Mainstream Classroom", Portsmouth, NH: Heinemann, 2002.

[18] R. Dunn, "Learning Styles of the Multiculturally Diverse," Emerg. Libr., Vol. 20, No. 4, pp. 24-32, 1993.

[19] R. M. Felder dan R. Brent, "Understanding Student Differences," J. Eng. Educ., Vol. 94, No. 1, pp. 57-72, 2005.

[20] S. Anik, "Proses Berpikir Siswa Kelas IX-G SMP Negeri I Wlingi Dalam Memecahkan Masalah Persamaan Garis Lurus dengan Scafolding," Makalah Prosiding Konferensi Nasional Pendidikan Matematika, Malang 27-30 Juni 2013, 2013.

[21] S. E. Toulmin, "The Uses of Argument", Second Edition. Cambridge, UK: Cambridge University Press., 2003.

[22] S. Gholami, "Relationship Between VAK Learning Styles and Problem Solving Styles regarding Gender and Students' Fields of Study," J. Lang. Teach. Res., Vol. 4, No. 4, pp. 700-706, 2013.

[23] S. H. Landry, K. E. Miller-Loncar, C. L.Smith, and P. R. Swank, "The Role of Early Parenting in Children's Development of Executive Processes.," Dev. Neuropsychol., Vol. 21, pp. 15-41, 2010.

[24] T. H. Lin, Y. Y. Hsu, S. S. Lin, M. L. Changlai, K. Y. Yang, and T. L. Lai, "A Review of Empirical Evidence on Scaffolding For Science Education," Int. J. Sci. Math. Educ., Vol. 10, pp. 437-455, 2012.

[25] T. Lehmann and D. Ifenthaler, "Influence of Students' Learning Styles on the Effectiveness of Instructional Interventions," Int. Conf. Cogn. Explor. Learn. Digit. Age, pp. 180-188, 2012.

[26] "VAK Test.," Discov. your Prefer. Learn. Style. Retrieved Desember, 2015 http//www.brainboxx.co.uk/a3_aspects/pdf/VAK_questionnaire.pdf. 